\title{
The Effectiveness of Marketing Mix Strategies on Competitiveness: A Case of Food Micro and Small Enterprises in Masvingo, Zimbabwe.
}

\author{
Munyaradzi Mutsikiwa ${ }^{1}$, Clay Hutama Basera ${ }^{1}$, Kossam Dhliwayo ${ }^{1}$, Jonatan Muzangwa $^{1}$ \\ ${ }^{1}$ Great Zimbabwe University
}

\begin{abstract}
The study seeks to investigate how Food Micro and Small Enterprises (FMSEs) (particularly restaurants) employ the $7 P s$ marketing mix strategy framework to enhance competitiveness measured in terms of patronage. The major emphasis is centered on the synergistic contribution of product, price, place, promotion, physical evidence, people, and process to enhancing competitive advantage to the enterprise. The researchers adopt a descriptive survey research design which enables them to establish consumers' propensity to frequent the FMSEs' outlets. The sample size includes 95 regular customers and 20 people from management. The major finding of this research indicates that, the application of the $7 p s$ framework plays an insignificant role in enhancing competitiveness serve for product and place variables.
\end{abstract}

Keywords: Food Micro and Small Enterprises, marketing mix strategies, competitiveness

\section{BACKGROUND TO THE STUDY}

During the past three decades the growth and development of micro and small enterprises has transformed considerably. The micro and small enterprises (MSEs) have thrived over varying periods and even in the era of economic meltdown they formed the backbone of people's economic activity and source of income. In Zimbabwe the importance of micro and small enterprises in contributing to job creation and output growth is now widely accepted. The MSEs are generally labour intensive and as a consequence create employment at low cost for those people who could not find employment in the other sectors of the economy. The MSEs were largely based in rural areas, particularly at growth points (development centres) but started to spread their wings into urban areas to cushion those people who were retrenched as a result of Economic Structural Adjustment Programmes. The sector is dominated by small manufacturers and traders. There is an emerging trend that MSEs have commenced to venture into the service sector. The bulk of these are run by at least three or more people. Overall, the Food MSEs in Zimbabwe depict a considerable degree of dynamism in terms of growth and income generation.

The government of Zimbabwe has acknowledged that the MSEs sector is the engine for growth and development of the economy. As a result, the Ministry of Micro, Small and Medium Enterprises developed a policy and strategy framework which outlined the strategies and the support measures which the ministry would provide in support of the growth of MSEs (McPherson, 1991). The major goals of the policy and strategic framework was to have sustainable, strong, vibrant and dynamic Micro, Small and Medium Enterprises that are well integrated into the main stream economy. The key objective was to clearly define how the government, the private sector and other stakeholders could encourage and create an enabling environment for MSEs to grow and enhance the contribution to national development. The MSEs were expected to create the much needed employment for the youth and opportunities for informal apprenticeship. They have managed to live to the expectations of their mandate although in most cases they have encountered challenges of sustenance. 


\section{LITERATURE REVIEW}

\subsection{Micro and Small Enterprises}

Many accomplished writers have come up with several definitions of micro and small enterprises depending on the number of people employed, contribution towards Gross Domestic Product (GDP) and the level of economic growth and development of a country. According to Elaian (1996) as quoted in The United International Development Organization (UNIDO) defines Micro and Small Enterprises in terms of the number of employees. Thus in developing countries micro firms employ less than five people and small firms are run by 5-19 people. The Bolton Committee (1971) developed an economic and statistical orientation towards the definition of what constitutes a small firm. From an economic point of view the committee says a firm is deemed small when it has a relatively small share of the market; when it is managed by the owner and when it is independent. From a statistical perspective the size of a firm depends on its contribution to GDP, employment and exports. It is evident from the various definitions that there is not a general consensus over what constitutes an MSEs. Definitions vary across industries and also across countries.

\subsection{Marketing Strategy}

The sustainability of any business, whether micro or small is dependent on a sound strategy. The term strategy has its roots in military circles which date back to the ancient Greek position of strategos of $507 \mathrm{BC}$ and the documentation of Sun Tzu the greatest Chinese war strategist. Johnson et al (2008:3) define strategy as “... the direction and scope of an organization over the long term, which achieves advantage in a changing environment through its configuration of resources and competence with the aim of fulfilling stakeholder expectations." In another definition Kotler and Armstrong (2004) view strategy as an organization's long term course of action designed to deliver a unique customer experience while achieving its goals. From the aforementioned definitions, a firm's strategy entails the competitive moves and business approaches that managers and executives employ in order to grow the business, attract and please customers, compete successfully, conduct operations and achieve targeted levels of organizational performance. Therefore it is a prerequisite for Food Micro and Small Enterprises to put in place strategies that will assist them to attain their goals. McDonald (2008) views strategic marketing as a structural way of identifying a range of options for the company, of formulating marketing objectives which are consistent with the company's overall objectives and of scheduling and costing out specific.

\section{MARKETING MIX STRATEGIES FOR FOOD MICRO AND SMALL ENTERPRISES}

Several renowned writers and researchers around the globe have coined the concept of the marketing mix strategy into several typologies depending on the type of business an entity will be in. Woldelul (2004) in her article entitled "Marketing strategies for Micro and Small enterprises in Ethiopia" adopts a 5Ps approach to marketing strategy in which she hails that marketing strategy is all about developing a good blend of the marketing mix elements namely: product, price, place/channel of distribution, promotion and person/process. Blending these key marketing variables will enable Food Micro and Small Enterprises to create and maintain a sustainable competitive advantage. From a services marketing point of view, an effective marketing mix strategy is hinged upon the so called "7 Ps" of marketing (Lovelock et al, 2011), namely the product, price, place, promotion, process, physical evidence and people. Food Micro Enterprises have a dual orientation in that they deal with the physical products (i.e. different cooked food menus) and intangibles. According to Kotler et al (1999) an effective marketing mix strategy is built on 4Ps namely product, price promotion and place which are translated into the 4Cs namely commodity, cost, communication, and convenience respectively.

\subsection{The Product}

Etzel M et al (1994), view the term product from a 
more holistic perspective as ".....a set of tangible and intangible attributes including packaging, colour, price, quality and brand, plus the sellers services and reputation that consumers gain from buying a product". This is echoed by Russ and Kirkpatrick (1982), who claim that a product is a bundle of need satisfying attributes and that when consumers buy a physical good they in fact will be seeking benefits. Because the product is at the heart of marketing strategy the need to manage it strategically is of paramount importance, since how well this is done is key both to the food micro enterprises`overall financial performance and the gaining and retaining of the market share, (Pearson J, 1992). Thus effective management of products and/or services by food micro and small enterprises should be aimed at balancing of costs, risks and returns. In Zimbabwe most Food Micro and Small Enterprises have similar lines of business, an aspect which demonstrates lack of diversity there by crowding the food market with undifferentiated offerings. Firms in this category may also have challenges in modifying their offerings and as result their competitive advantage may be eroded and thus can only thrive in such a highly competitive market as price takers and not price setters.

\subsection{Price}

Most strategic marketing thinkers undoubtedly believe that price is a significant strategic variable in most if not all markets, despite the growth in the importance of non price factors. Marketers and consumers alike still view this variable as the principal indicator of value for product and/or service. Kotler and Armstrong (2004) assert that pricing is an important strategic marketing mix element as it is the only tool that generates revenue while all other elements generate costs. Price is the money or other considerations (including, other goods and services) exchanged for the ownership or use of a good or service, (Kerin, 2009). When setting up the prices for Food Micro and Small Enterprises, a number of factors are considered, viz the nature of competition and type of market structure, business objectives, costs and other significant environmental variables and the nature of the targeted consumers in relation to their perception of the product-price value relationship.

Food Micro and Small Enterprises normally suggest prices that their customers may be willing to pay. The price of the items on the menu may also greatly influence customers because price has the capability of attracting or repelling them (Monroe, 1989), since price functions is an indicator of quality (Lewis and Shoemaker, 1997). If the price is high, customers are likely to expect high quality, or it may induce a sense of being "ripped off." Likewise, if the price is low, customers may question the ability of the restaurant to deliver product and service quality. This indicates that the price offering for the restaurant needs to be in accordance with what the market expects to pay to avoid negative deviation. According Blythe (2003), proper pricing helps an organization to achieve strategic outcomes especially if the prices are market driven since developing a pricing strategy based on market expectations are a key means for establishing competitive advantage.

\subsection{Place}

The place where customers purchase a product or service and the means with which the product is made available to that place must create convenience to the customer. The main objectives of the place strategy include the following: getting the right product, at the right price, in the right quantity, at the right time and the right place. With regards to Food Micro and Small Enterprises, consumers expect those foods outlets to offer food menus of the right qualities and right quantities consummate with the money they pay. Customers also expect these businesses to be convenient and easily accessible. The term place refers to the distribution aspect which is related to the development of the arrangements necessary to transfer ownership of product and transport the product from the producer to the consumer.

\subsection{Promotion}

Cravens and Piercy (2006) view promotion strategy as a “... process of planning, implementing and controlling a firm`s communications to its targeted and potential markets."

Promotion is a blanket term which embraces all forms of marketing communications (including 
advertising, sales promotion, public relations and publicity, personal selling and direct marketing) that business practitioners tactfully employ to persuasively communicate customer value and create long term customer relationships (Kotler and Armstrong, 2008).

The role of promotional mix therefore is to create and enhance awareness on targeted audience about the availability of services and products in the market-place. Effective integration and correct blending of the promotion mix variables by Food Micro and Small enterprises help them to develop a sound communications mix strategy which is key to developing competitiveness for individual players in the sector.

\subsection{Physical evidence}

Booms and Bitner (1991) view physical evidence as "... the environment in which the service is assembled and the seller and consumer interact, combined with tangible commodities that facilitate performance or communication of the service." This depicts the actual physical and material settings designed to influence consumer behavior patterns. This is also echoed by many researchers who have demonstrated that physical evidence plays a significant role in enhancing both positive and negative impressions about the provider of a service (Bitner, 1992). Physical evidence provides the tangible aspect of the service product as it provides cues to customers on what to expect and creates a perceptual image in the minds of customers (Kotler et al, 1999). The design of a conducive physical environment or services cape is critical. The appearance of buildings, landscaping vehicles, interior décor, equipment, employees`dressing, signage, printed material and other visible cues are strategic variables of physical evidence which adorn a service organization and provide tangible evidence about the kind of service a firm offers and this facilitates service delivery. Food Micro and Small Enterprises need to foster the validity of physical evidence as impression has a profound impact on customer satisfaction and thereby creating competitive advantage.

\subsection{People}

Lovelock and Wirtz, (2011) assert that employees, especially those working in direct contact with clientele are key input for enhancing excellent service delivery and this fosters competitive advantage for the Food Micro and Small Enterprises. Therefore the secret behind successful service for most service oriented organizations is their commitment to effective management of the people element which is anchored on good recruitment and selection, motivation and retention of workers. Organizations (small or large) that have fully committed themselves to adopting such a strategic orientation understand the economic payoff associated with investing in the people element as a strategic tool for competitiveness. Gummerson (2001) as quoted by Palmer (2005) argues that in service-product based organizations such as Food Micro and Small Enterprises every employee is a part-time marketer in that their collective actions have a direct bearing on what consumers ultimately receive and consume. In organizations where customer-employee interface is high people planning is critical, hence the need for management to commit themselves to good recruitment, grooming, motivation and fair remuneration of employees as key marketing mix decisions for harnessing competitiveness.

\subsection{Process}

The process of rendering a service and the interactive behavior of internal employees should best-fit the service delivered to customers so that process becomes a key determinant of customer satisfaction. According to Thomas Davenport as quoted by Christopher and Peck (2003), the term process refers to "....any activity or group of activities that takes an input, adds value to it and provides an output to an internal and external customer." Organizational processes should be integrative in nature and should be aimed at meeting the strategic goals of an organization as well as creating, enhancing and delivering customer value and ultimate satisfaction. In order to attain the aforementioned, the enterprises have to follow solid procedures and policies that they put in place. These are guided by a thorough knowledge with regards to the importance of the services to the customers, their being provided timeously to the customer and if customers are communicated to (Lin, 2011). If Food Micro and 
Small Enterprises strike a balance on the key issues of this marketing mix element, there is a high probability that they may be competitive enough to outwit competitors in the marketplace.

\section{COMPETITIVENESS}

Food Micro and Small Enterprises are operating in a challenging and fast dynamic environment and the need for attaining competitive advantage is increasingly becoming important. Competitiveness entails a multidimensional concept in the sense that being competitive calls for the ability to effectively blend the marketing mix elements better than competitors. According to Blunk (2006), competitiveness is the ability to provide products and services as/or more effectively and efficiently than the relevant competitors. Porter (1990), also notes that competitiveness is dependent upon the ability of an enterprise to adopt highly effective, efficient and productive strategies such as new innovations, effective marketing strategies and qualified associates. An enterprise is regarded as having a competitive advantage when it implements bestfitting strategies that create more value through providing additional benefits and services.

\section{HYPOTHESES}

The following hypotheses were developed to establish the relationship between marketing mix variables and the competitiveness of Food Micro and Small Enterprises. The basis upon which the hypotheses are built is that if the marketing mix variables are effectively blended as a marketing strategy they can enhance competitiveness for a small marketing oriented business.

H1: Product performance has a positive impact on competitiveness/patronage.

H2: The attractiveness of pricing has a positive bearing on attracting customers.

H3: The site of an enterprise shop has a positive effect on competitiveness/patronage.

H4 Promotion has a positive impact on patronage H5: Physical evidence of an enterprise does not have a strong influence on competitiveness/ patronage.

H6: Employees have a positive bearing on competitiveness/ patronage.
H7: Processes have a negative effect on competitiveness/patronage

\section{METHODOLOGY}

This research sought to establish the effectiveness of the marketing mix strategies in enhancing the competitiveness of Food Micro and Small Enterprises in Masvingo Urban, Zimbabwe. We employed the 7 Ps (Product, Price, Promotion, Place, People, Processes and Physical evidence) in an attempt to assess how far the aforementioned enterprises effectively blended these variables to create competitive advantage. A descriptive research design was adopted as it allowed the respondents to give their views pertaining to problem under study. It also facilitated the researchers to examine the relationship between marketing mix variables and competitiveness of the enterprises.

To measure the relationship between the marketing mix variables and competitiveness a questionnaire guide was employed to solicit data from the respondents (customers and management). The questionnaire focused on seven key variables namely: product (quality, variety, portion size, brand name), price ( fee charged, credit terms, discounts allowed, time pricing), place (location, accessibility, convenience, inventory/ stocks), promotion (sales promotion, personal selling, public relations, advertising), physical evidence (décor, nature of buildings, ambience, hygiene), people (customer care skills, training, motivation, uniforms) and processes (greetings, menu information, ordering time, and waiting time). We employed an ordinal scale where respondents were asked to rank marketing mix attributes on a scale (poor, not sure, average, and good). It was done in order to assess the customers' views on how Food Micro and Small Enterprises have effectively applied the marketing mix variables in order to sustain competitiveness.

We employed convenience sampling in which respondents were interviewed on the basis of their willingness to participate on the study. Consumers were intercepted as they were coming to patronize the services offered by these outlets.

\subsection{Data analysis and results}


Since the purpose of the research was to assess the effectiveness of the marketing mix strategies (product, price, place, promotion, physical evidence, people and processes) on competitiveness of Food Micro and Small Enterprises, a multiple linear regression model was employed to establish the relationship:

$\bar{Y}_{i}=\beta_{0}+\beta_{1} \dot{X}_{1 i}+\beta_{2} \dot{X}_{2 i}+\beta_{3} \dot{X}_{3 i}+\beta_{4} \dot{X}_{4 i}+\beta_{5} \dot{X}_{5 i}+$ $\beta_{6} \dot{X}_{6 \mathrm{i}+}+\beta_{7} \dot{X}_{7 \mathrm{i}}+\epsilon_{1}$

$\bar{Y}=$ competitiveness (measured in terms of patronage), $\quad \dot{\mathrm{X}}_{1}=$ product, $\dot{\mathrm{X}}_{2}=$ price, $\dot{\mathrm{X}}_{3}=$ place, $\quad \dot{X}_{4}=$ promotion, $\dot{X}_{5}=$ physical evidence, $\dot{\mathrm{X}}_{6}=$ people, and $\dot{\mathrm{X}}_{7}=$ processes.

We computed the data using SPSS and the following results were obtained as shown on the tables. We employed the results on the first and second tables to analyse the data collected.

ANOVA Table 1

\begin{tabular}{|cc|c|c|c|c|c|}
\hline & Model & $\begin{array}{c}\text { Sum of } \\
\text { Squares }\end{array}$ & df & $\begin{array}{c}\text { Mean } \\
\text { Square }\end{array}$ & F & Sig. \\
\hline $1 \quad$ Regression & 3.418 & 7 & .488 & .889 & $.518^{\mathrm{a}}$ \\
& & & & & \\
& Residual & 58.756 & 107 & .549 & & \\
& Total & 62.174 & 114 & & & \\
\hline
\end{tabular}

a. Predictors: (Constant), Process average, Promotion average, Price average, Place average, Product average, People average, Evidence average

b. Dependent Variable: frequency of purchase per week

$\mathrm{F}_{0.95,6,798}=2.10$ is greater than the $\mathrm{F}$ calculated value (.889), therefore we accept $\mathrm{H}_{0}$ that the mean responses are not significant. Therefore this means the contribution of each variable towards competitiveness is almost the same.

Table 2.Shows the results of the multiple regression computed using SPSS.

\begin{tabular}{|c|c|c|c|c|c|}
\hline \multirow[b]{2}{*}{ Model } & \multicolumn{2}{|c|}{ Unstandardized Coefficients } & \multirow{2}{*}{$\frac{\text { Standardized Coefficients }}{\text { Beta }}$} & \multirow[b]{2}{*}{$\mathrm{t}$} & \multirow[b]{2}{*}{ Sig. } \\
\hline & B & Std. Error & & & \\
\hline (Constant) & 1.760 & .582 & & 3.023 & .003 \\
\hline Product average & .153 & .114 & .143 & 1.335 & .185 \\
\hline Price average & -.013 & .110 & -.012 & -.121 & .904 \\
\hline Place average & .119 & .111 & .113 & 1.068 & .288 \\
\hline Promotion average & -.119 & .100 & -.123 & -1.196 & .234 \\
\hline Evidence average & .083 & .120 & .082 & .692 & .490 \\
\hline People average & -.005 & .126 & -.004 & -.038 & .969 \\
\hline Process average & -.099 & .120 & -.091 & -.822 & .413 \\
\hline
\end{tabular}

a. Dependent Variable: Frequency of purchase per week

\section{RESULTS}

Hypothesis 1 postulates that product performance has a positive impact on competitiveness or patronage. It was tested to assess the effect of product attributes (quality, variety, portion and brand name) on competitiveness. $\mathrm{H}_{0:} \beta=0$ versus $\mathrm{H}_{1}=\beta \neq 0 ; \mathrm{t}_{(0,025,114)}=1.96$ compared with $\mathrm{t}_{\text {cal }}=$ 1.335 , therefore we accept $\mathrm{H}_{0}$. The results depict that variable $\mathrm{X}_{1}$ has a positive effect though not significant. This demonstrates that in general product attributes are not significant determinants of Food Micro and Small Enterprises store patronage. Such results may be so because these businesses operate more like stop gap measures for convenience to the customers.

Hypothesis 2 indicates that the attractiveness of pricing has the positive bearing on attracting customers; this is supported by Monroe (1989) who asserts that price has the capability of 
attracting or scaring away customers. We therefore consciously accept the hypothesis traced because the results of the t-test $(-.21)$ indicate that there is an insignificant contribution towards enhancing patronage. This may be so because most, if not all players in this business sector charge uniform prices and the nature of business depicts a pure competition type of market structure.

Hypothesis 3 postulates that proper sitting of a business whether small or big, has a positive influence on enhancing patronage. The results of the t-test (1.068) demonstrate that indeed the site of a business positively influences patronage. Comparatively (as shown in the table) place and product have a reasonable measure of influence. This may be so because these small businesses are normally situated strategically in places convenient to the customers such as along the roads, to cater for travellers, city centres to cater for general public and workers based in town, and industrial sites.

Hypothesis 4 postulates that promotion creates and enhances awareness and persuades targeted audience to prefer certain product or service providers over others. This hypothesis connotes that if promotion is undertaken by a Food Micro and Small Enterprises it will enhance its competitiveness (patronage) The results of the $t-$ test (-1.196) are indicative of the factor that such businesses by virtue of their operations thrive well even without making use of formal promotions such as advertising and personal selling.

Hypothesis 5 postulates that physical evidence of an enterprise does not have a strong influence on competitiveness/patronage. This is supported by Bitner (1992) who contents that physical evidence can create both positive and negative impressions about the service provider as has been shown by the t-test results (.692). The role of physical evidence has often been relegated by owners of Food Micro and Small Enterprises. This is because most of their operations are done as backyard operations unlike the operation of the more formalized businesses which have designated stands and front office operations in which physical evidence is critical.

Hypothesis 6 postulates that employees have a positive bearing on enhancing store patronage.
Although this is supported by Palmer (2005) that every employee is a part-time marketer and contributes towards what the consumer receives and consumes, the results of the t-test (-.038) is indicative of the fact that in such business operations, the people element does no play a vital role in influencing patronage. This may be so because most of the customers in such a market focus much of their attention on the product and perhaps price and are less sensitive to role of the employees in enhancing the quality of the overall service provision. There other issue is that most of the service providers emphasize on take away products and therefore there is minimal interaction of customers.

Hypothesis 7 asserts that process has a negative effect on patronage and the result of the t-test (.822) confirm that process has an impact on enhancing patronage. Processes are usually back stage operations and as such customers are usually exposed to already prepared products without actually witnessing activities associated with the preparation process. Because of this customers are less sensitive to the process as an important marketing mix variable.

\section{CONCLUSIONS}

The primary objective of this study was to investigate how Food Micro and Small Enterprises employ the 7Ps marketing mix strategy framework to enhance competitiveness. The results from the research indicated that the application of the $7 \mathrm{ps}$ framework plays an insignificant role in enhancing competitiveness. However, the product and place variables have a relatively stronger contribution towards the competitiveness of the enterprises. The marketing implications of the results are that proprietors of Food Micro and Small Enterprises need to harness product and place strategy to effectively create competitiveness. While the other Ps are of less defined practical significance still need to employ them as they also contribute towards meeting the minimal acceptable standard expected by customers.

\section{FURTHER RESEARCH}


The research had limitations as it only focused on Food Micro and Small Enterprises in Masvingo urban and did not extend to the other geographic areas. The researchers used a smaller sample and were only confined to few selected enterprises. The researchers feel that there is need for a more concerted effort in which the seven Ps marketing mix strategy framework will be applied to larger food and beverage organisations in Zimbabwe.

\section{REFERENCES}

[1] Kotler, P., Armstrong, G., and Wong, V. (1999). Principles of Marketing, $2^{\text {nd }}$ Edition.Upper Sadle River: Prentice Hall.

[2] Blunk, F. (2006). What is Competitiveness?

http:www.copmetitiveness.org/article/ar ticleview/774/32.

[3] Bolton Committee (1971Bolton, J. E. (1971). "Report of the Committee of Inquiry on Small Firms", HMSO, London.

[4] Christopher, M and Peck, H. (2003). Marketing Logistics, $2^{\text {nd }}$ Edition, Butterworth Heinmann.

[5] Cravens, D and Piercy, N. F. (2006). Strategic Marketing, $8^{\text {th }}$ Edition.

[6] Elaian, K. (1996). Employment Implications of Small Scale Industries in Developing Countries: European Union Commission (2003) Commission of the European Communities (1996), 'Commission recommendation of April, 31996 concerning the definition of small and medium-sized enterprises.'

[7] Etzel, M. J; Santon, W. J; and Walker, B. J. (1994).Fundamentals of Marketing, McGraw Hill.
[8] Johnson et al (2008). Exploring Corporate Strategy: Text $\&$ Cases, $8^{\text {th }}$ Edition, Cape Town, Prentice Hall.

[9] Kerin, R.A., E.N. Berkowitz, S.W. Hartley, and W. Rudelius (2009), Marketing, New York: McGraw-Hill.

[10] Kotler, P and Armstrong, G. (2008). Principles of Marketing. Global and South African Perspectives, $12^{\text {Th }}$ Edition, Pearson Prentice Hall.

[11] Lovelock, C and Wirtz, J. (2011). Services Marketing. People, Technology, Strategy. $7^{\text {th }}$ Edition, Pearson.

[12] McPherson, A. S. (1991). Micro, SmallScale Enterprises in Zimbabwe: Results of a Country-Wide Survey, Michigan State University.

[13] Palmer, A. (2005). Principles of Services Marketing $4^{\text {th }}$ Edition, Mc GrawHill.

[14] Pearson, D. J. (1992). Strategic Marketing Management: Planning Implementation and Control, Butterworth Heinmann.

[15] Porter, M.E. (1990). Competitive Strategy, London: Collier Macmillan Publishers.

[16] Russ, F. A.and Kirkpatrick, C. A. (1982) Marketing

[17] Ulrich, D. (1998). A New Mandate for Human Resources. Harvard Business review, Jan/Feb 124-134.

[18] Woldelul, A. (2004). Marketing Strategies For Micro and Small Enterprises In Ethiopia. Addis Ababa, Ethiopia. 